Victoria Ellerbroek*, Katharina Warncke, Julia Köhle and Walter Bonfig*

\title{
A levothyroxine dose recommendation for the treatment of children and adolescents with autoimmune thyroiditis induced hypothyroidism
}

\begin{abstract}
Objective: To determine a levothyroxine (T4) dose recommendation for the treatment of autoimmune thyroiditis (AIT)-induced hypothyroidism.

Methods: T4 doses in 75 children and adolescents with newly diagnosed AIT were prospectively collected and compared to T4 doses of patients with congenital hypothyroidism ( $\mathrm{CH}, \mathrm{n}=22)$.

Results: Sixty-four patients with AIT and 22 patients with $\mathrm{CH}$ were included in the analysis. The thyroid-stimulating hormone declined significantly from $25.8 \pm 50.1$ to $2.1 \pm 1.5 \mu \mathrm{IU} / \mathrm{mL}$ (AIT group; $\mathrm{p}<0.01$ ) and from $338.7 \pm 380.7$ to $1.9 \pm 1.6 \mu \mathrm{IU} / \mathrm{mL}$ (CH group; $\mathrm{p}<0.01$ ). The required $\mathrm{T} 4$ dose for patients with AIT was $1.5 \pm 0.5 \mu \mathrm{g} / \mathrm{kg}$ per day $(\geq 6$ to $<10$ years: $2.0 \pm 0.4 \mu \mathrm{g} T 4 / \mathrm{kg}$ per day; $\geq 10$ to $<12$ years: $1.6 \pm 0.4 \mu \mathrm{g} \mathrm{T} 4 / \mathrm{kg}$ per day; $\geq 12$ to $<14$ years: $1.5 \pm 0.6 \mu \mathrm{g} \mathrm{T} 4 / \mathrm{kg}$ per day; $\geq 14$ years: $1.4 \pm 0.6 \mu \mathrm{g} 4 / \mathrm{kg}$ per day). It deviated significantly from the $\mathrm{CH}$ patients' mean $\mathrm{T} 4$ dose of $2.8 \pm 0.7 \mu \mathrm{g}$ T4/ $\mathrm{kg}$ per day, $\mathrm{p}<0.01$. CH patients with athyreosis required an average dose of $3.1 \pm 0.5 \mu \mathrm{g}$ T $/ \mathrm{kg}$ per day; patients with ectopia, $2.6 \pm 0.7 \mu \mathrm{g}$ T4/kg per day; and patients with dyshormonogenesis, $2.5 \pm 0.6 \mu \mathrm{g} \mathrm{T} 4 / \mathrm{kg}$ per day. Conclusion: Juvenile patients with AIT require significantly lower $\mathrm{T} 4$ doses than patients with $\mathrm{CH}$.
\end{abstract}

Keywords: autoimmune thyroid disease; Hashimoto's thyroiditis; pediatric hypothyroidism; thyroxine.

\footnotetext{
*Corresponding authors: Victoria Ellerbroek and Walter Bonfig, Department of Pediatrics, Children's Hospital, Technical University of Munich, Parzivalstr. 16, 80804 München, Germany, Phone: +49 893068 2589, Fax: +49 893068 3849, E-mail:vellerbroek@gmx.de; Walter.Bonfig@lrz.tum.de Katharina Warncke and Julia Köhle: Department of Pediatric Endocrinology, Children's Hospital, Technical University of Munich, Germany
}

\section{Introduction}

Two of the most common endocrine diseases in childhood and adolescence are autoimmune thyroiditis (AIT, also known as Hashimoto thyroiditis) and congenital hypothyroidism $(\mathrm{CH})$, with a prevalence of $1.27 \%-9.6 \%$ and 1:1800-4000, respectively (1-4). These conditions can lead to potentially devastating long-term effects, affecting growth, pubertal and, in case of $\mathrm{CH}$, intellectual development, if not treated with an adequate levothyroxine (T4) substitution $(5,6)$. Although both diseases are widespread, intense pediatric literature research displayed a lack of specific evidence-based and age-appropriate maintenance dose recommendations for T4 supplementation of hypothyroid pediatric patients with AIT. Either dosage suggestions are missing, as in the current German national guideline for AIT, or there are only sparse recommendations available without descriptions of patients, methods and procedure (7-9).

In contrast, there are various therapy outlines for the treatment of $\mathrm{CH}$, for example, by the American Academy of Pediatrics, American Pharmacist Association and German Society of Endocrinology and Pediatrics and Adolescent Medicine (10-12). Authors usually speculate that the required $\mathrm{T} 4$ dosages might be similar to those required in $\mathrm{CH}(13,14)$. Subjective perception and clinical experience, however, gave the impression that both patient groups have significantly different needs.

This study compares the T4 dose of AIT patients to data of a control group with $\mathrm{CH}$. The study objective was to find a maintenance dose of T4 capable of lowering the concentrations of thyroid-stimulating hormone (TSH) in serum to the lower normal range in AIT and $\mathrm{CH}$ subjects, as suggested by Baloch et al. (15).

\section{Materials and methods}

\section{Subjects and inclusion criteria}

Between January 2009 and December 2010, a total number of 75 children and adolescents younger than 18 years of age with newly diagnosed AIT-induced hypothyroidism were prospectively included in this study. At the end of the study, they were compared to the follow-up data of 22 compliant patients with congenital hypothyroidism who had a stable euthyroid status for the last two visits in this time period and have already been treated since birth in our clinic. 
The diagnosis was based on medical history, clinical symptoms and examination, ultrasonography and laboratory criteria. In patients with AIT, antithyroid peroxidase antibodies (anti-TPO Ab) and/or antithyroglobulin antibodies (anti-TG Ab) were positive and high-resolution ultrasonography revealed typical hypoechogenicity of thyroid tissue. AIT patients were included for T4 treatment and analysis when they were hypothyroid [low fT4 and elevated TSH - for TSH, fT3 and fT4 normal range see the Laboratory Evaluation section and reference (16)] and between 6 and 18 years of age. Patients with $\mathrm{CH}$ were included with an initial TSH at birth of $>15.2 \mu \mathrm{IU} / \mathrm{mL}$ (1-6-day-old newborns) and $>11.0 \mu \mathrm{IU} / \mathrm{mL}$ (newborns $>6$ days to $\leq 3$ months). At the time of the study, they were also supposed to be between 6 and 18 years of age and compliant in taking their T4 medication. Furthermore, their TSH and fT4 levels were supposed to be constantly in the normal range for at least the last two visits.

For adjustment of T4 dosage, patients were seen 4 weeks after the start of therapy and every 3 months at the Pediatric Endocrinology outpatient clinic of the Technical University of Munich. Upon therapy onset and during the follow-up visits, age, height and weight were recorded. The body surface was calculated by the formula of Mosteller (17).

Due to subjective perception and clinical experience, patients with AIT were given a lower initial dose per kilogram than what patients with $\mathrm{CH}$ usually received. Treatment target was a TSH in the age-specific lower normal range (15). Dose adjustments took place in further follow-up visits depending on the outcome of the clinical examination and laboratory results. The daily dose of T4 was adapted to the patient's current weight.

The study was closed when the majority of patients had a stable euthyroid status with a TSH in the normal range for at least two visits. This was 17.2 months after the start of the study.

The T4 dose of each patient group (AIT versus $\mathrm{CH}$ ) was compared by disease severity and at a similar age. For further analysis, patients were divided into four age groups ( $\geq 6$ to $<10, \geq 10$ to $<12, \geq 12$ to $<14$ and $\geq 14$ years). The $\mathrm{CH}$ patients were also analyzed by disease etiology (athyreosis, ectopia and dyshormonogenesis).

AIT Patients were excluded from analysis due to non-compliance or drop out.

The study protocol was approved by a local ethics committee and informed consent was obtained by both patients and their guardians.

\section{Laboratory evaluation}

Free T3, free T4, TSH and anti-TPO Ab and anti-TG Ab (only for AIT subjects) concentrations were measured after serum samples were obtained at presentation and during the follow-up visits. The blood samples were analyzed in vitro by the Institute for Clinical Chemistry and Pathobiochemistry of the Technical University of Munich. Laboratory analysis was conducted with commercial test kits (Roche Cobas, Roche Diagnostics GmbH, Mannheim, Germany) in a competitive assay using electrochemiluminescence detection. It was performed on a Cobas e 411 analyzer (Roche Diagnostics). The corresponding standard values were obtained from the company's manual (16) as follows: TSH (in $\mu \mathrm{IU} / \mathrm{mL}$ ): $0-6$ days $=0.7-15.2$; $>6$ days to $\leq 3$ months $=0.72-11.0$; $>3$ to $\leq 12$ months $=0.73-8.35$; $>1$ to $\leq 6$ years $=0.7-5.97 ;>6$ to $\leq 11$ years $=0.6-4.84 ;>11$ to 20 years $=0.51-4.3$.
The normal values for fT 4 (pmol/L) were as follows: $0-6$ days $=11.0-$ 32.0; $>6$ days to $\leq 3$ months $=11.5-28.3$; $>3$ to $\leq 12$ months $=11.9-$ 25.6 ; $>1$ to $\leq 6$ years $=12.3-22.8 ;>6$ to $\leq 11$ years $=12.5-21.5 ;>11-20$ years $=12.6-21.0$. For $\mathrm{fT} 3$ (in pmol/L) they were as follows: $0-6$ days $=$ $2.65-9.68$; $>6$ days to $\leq 3$ months $=3.0-9.28$; $>3$ to $\leq 12$ months $=3.3-$ 8.95 ; $>1$ to $\leq 6$ years $=3.69-8.46$; $>6$ to $\leq 11$ years $=3.88-8.02$; $>11$ to 20 years $=3.93-7.7$.

\section{Statistical analysis}

The statistical data collection and analysis were carried out with IBM SPSS Statistics (version 20, IBM, Chicago, IL, USA). After testing for normal distribution (Kolmogorov-Smirnov test and bar charts with Gaussian distribution curve), the Student's t-test was used for comparisons between parametric data. For comparisons between data of the initial and follow-up visit of each group, the paired Student's t-test was applied. Nonparametric data of unpaired samples were compared by the Mann-Whitney U-test and paired samples with the Wilcoxon signed-rank test. Frequencies were assessed with the $\chi^{2}$ test. In all tests, a $\mathrm{p}$ value of $<0.05$ was considered significant and a $\mathrm{p}$ value of $<0.01$ was considered highly significant.

\section{Results}

The two groups did not differ significantly in sex distribution and in the four age groups at the last follow-up visit, as shown in Table 1.

Initially all patients with AIT were hypothyroid with a significantly elevated TSH at $25.8 \pm 50.8 \mu \mathrm{IU} / \mathrm{mL}$. At diagnosis of $\mathrm{CH}$ in the neonatal period, all patients with $\mathrm{CH}$ had significantly elevated TSH concentrations (Table 2). All patients $(\mathrm{N}=86)$ turned euthyroid in the course of $\mathrm{T} 4$ therapy. TSH sank significantly to the lower half (AIT and CH group: $\mathrm{p}<0.01$ ), and fT3 and fT4 rose significantly to the upper half of the normal range in both groups (AIT group: $\mathrm{p}<0.01$ ). The two groups did not have significantly different fT3, fT4 and TSH values at the last follow-up visit (Table 2).

At the end of the study, 64 (85.3\%) of 75 AIT patients fulfilled the inclusion criteria. Reasons for the exclusion of patients in the AIT group were drop-out of six patients and noncompliance of three patients. The noncompliant AIT patients had a mean TSH of $5.7 \pm 2.5 \mu \mathrm{IU} / \mathrm{mL}$, a mean fT3 of $3.8 \pm 1.7 \mathrm{pmol} / \mathrm{L}$ and a mean fT 4 of $12.2 \pm 4.3 \mathrm{pmol} / \mathrm{L}$.

The AIT patients' antithyroid antibody concentrations declined during the course of therapy: the anti-TPO $\mathrm{Ab}$ titer decreased significantly from $1284.4 \pm 1864.1$ to 568.0 $\pm 603.7 \mathrm{IU} / \mathrm{mL}(\mathrm{p}<0.05)$, whereas decline in anti-TG Ab titers failed statistical significance $(\mathrm{p}=0.56)$ : anti-TG $\mathrm{Ab}$ at diagnosis, $758.0 \pm 196.5 \mathrm{IU} / \mathrm{mL}$; anti-TG Ab at followup, $713.3 \pm 218.7 \mathrm{IU} / \mathrm{mL}$. 
Table 1 Patients' characteristics: sex and age distribution (mean \pm SD, median and range) in the two treatment groups.

\begin{tabular}{|c|c|c|c|}
\hline & AIT & $\mathrm{CH}$ & p-Value \\
\hline No. of subjects & $\mathrm{n}=73$ & $\mathrm{n}=22$ & \\
\hline Sex & $f: 48, m: 25$ & $\mathrm{f}: 15, \mathrm{~m}: 7$ & \\
\hline \multicolumn{4}{|c|}{ Age at start of therapy } \\
\hline Total & $\begin{array}{l}11.6 \pm 2.6 \text { years (median: } 12.1 \\
\text { range: } 4.4-16.7 \text { years) }\end{array}$ & $\begin{array}{l}7.0 \pm 6.0 \text { days (median: } 7.0, \\
\text { range: } 1.0-19.0 \text { days) }\end{array}$ & $<0.01$ \\
\hline \multicolumn{4}{|l|}{ Age at follow-up } \\
\hline Total & $\begin{array}{l}13.2 \pm 2.4(\text { median: } 13.2 \\
\text { range: } 6.6-17.4)\end{array}$ & $\begin{array}{l}11.1 \pm 2.3(\text { median: } 10.9 \\
\text { range: } 6.2-15.1)\end{array}$ & $<0.01$ \\
\hline$\geq 6-<10$ & $\begin{array}{l}8.2 \pm 1.3 \text { (median: } 8.4 \\
\text { range: } 6.0-9.7 \text { ) }\end{array}$ & $\begin{array}{l}8.8 \pm 1.2 \text { (median: } 9.0 \\
\text { range: } 6.2-9.9 \text { ) }\end{array}$ & 0.39 \\
\hline$\geq 10-<12$ & $\begin{array}{l}11.2 \pm 0.6(\text { median: } 11.4 \\
\text { range: } 10.0-11.9)\end{array}$ & $\begin{array}{l}11.0 \pm 0.5(\text { median: } 10.9 \\
\text { range: } 10.5-11.8)\end{array}$ & 0.50 \\
\hline$\geq 12-<14$ & $\begin{array}{l}13.0 \pm 0.5(\text { median: } 12.9 \\
\text { range: } 12.0-13.9)\end{array}$ & $\begin{array}{l}12.6 \pm 0.4 \text { (median: } 12.7 \\
\text { range: } 12.0-13.0)\end{array}$ & 0.17 \\
\hline$\geq 14$ & $\begin{array}{l}15.3 \pm 0.9(\text { median: } 15.5 \\
\text { range: } 14.0-17.4)\end{array}$ & $\begin{array}{l}14.6 \pm 0.4(\text { median: } 14.7 \\
\text { range: } 14.1-15.1)\end{array}$ & 0.20 \\
\hline
\end{tabular}

\section{Required T4 dose}

In the newborn period, patients with $\mathrm{CH}$ received $13.0 \pm 3.5 \mu \mathrm{g}$ T4/kg per day. Patients with AIT-induced hypothyroidism were treated initially with an empirical dose of $1.6 \pm 0.5 \mu \mathrm{g} T 4 / \mathrm{kg}$ per day $(\mathrm{p}<0.01)$ at a mean age of $11.6 \pm 2.6$ years.

At follow-up, when TSH was within the desired range, the mean required $\mathrm{T} 4$ dose was $1.5 \pm 0.5 \mu \mathrm{g} 4 / \mathrm{kg}$ per day in the AIT group (mean age: $13.2 \pm 2.4$ years) and $2.8 \pm 0.7 \mu \mathrm{g}$ T $4 / \mathrm{kg}$ per day in the $\mathrm{CH}$ group (mean age: $11.1 \pm 2.3$ years $)(\mathrm{p}<0.01)$.
Looking at different age groups, a significant difference between the AIT and the $\mathrm{CH}$ group remained in terms of $\mathrm{T} 4$ requirement: $\geq 6$ to $<10, \geq 10$ to $<12$ and $\geq 12$ to $<14$ years: $p<0.01$; and $\geq 14$ years: $p<0.05$, as shown in Figure $1 \mathrm{~A}$.

Patients with AIT-induced hypothyroidism aged $>6$ to $<10$ years needed $2.0 \pm 0.4 \mu \mathrm{g}$ T4/kg per day; children aged $>10$ to $<12$ years, $1.6 \pm 0.4 \mu \mathrm{g}$ T4/kg per day; adolescents aged $>12$ to $<14$ years, $1.5 \pm 0.6 \mu \mathrm{g}$ T4/kg per day; and adolescents $>14$ years were optimally set up with $1.4 \pm 0.6 \mu \mathrm{g} \mathrm{T} 4 / \mathrm{kg}$ per day.

At a comparable age, patients with $\mathrm{CH}>6$ to $<10$ years of age required $3.1 \pm 0.5 \mu \mathrm{g}$ T4/kg per day; children $>10$

Table 2 Average serum concentrations of TSH, free T3 and free T4 (mean, SD, median and range) at onset of therapy and the follow-up visit.

\begin{tabular}{|c|c|c|c|}
\hline & TSH, $\mu \mathrm{IU} / \mathrm{mL}$ & fT3, pmol/L & fT4, pmol/L \\
\hline \multicolumn{4}{|l|}{ AIT } \\
\hline At start of therapy & $\begin{array}{l}25.8 \pm 50.1 \text { (median: } 7.5 \\
\text { range: } 4.4-280.0)\end{array}$ & $\begin{array}{l}3.7 \pm 0.8 \text { (median: } 3.7 \\
\text { range: } 1.4-6.3) \\
(2.4 \pm 0.5 \mathrm{pg} / \mathrm{mL} \text {, median: } \\
2.4 \text {, range: } 0.9-4.1)\end{array}$ & $\begin{array}{l}12.9 \pm 3.9(\text { median: } 12.9, \\
\text { range: } 1.3-19.3) \\
(1.0 \pm 0.3 \mathrm{ng} / \mathrm{dL}, \text { median: } 1.0, \\
\text { range: } 0.1-1.5)\end{array}$ \\
\hline At follow-up & $\begin{array}{l}2.1 \pm 1.5 \text { (median: } 2.0, \\
\text { range: } 0.1-7.1)\end{array}$ & $\begin{array}{l}5.7 \pm 0.9 \text { (median: } 5.7 \\
\text { range: } 1.8-7.3) \\
(3.7 \pm 0.6 \mathrm{pg} / \mathrm{mL} \text {, median: } \\
3.7, \text { range: } 1.2-4.8)\end{array}$ & $\begin{array}{l}18.0 \pm 5.1 \text { (median: } 16.7, \\
\text { range: } 10.3-54.0) \\
(1.4 \pm 0.4 \mathrm{ng} / \mathrm{dL} \text {, median: } 1.3 \text {, } \\
\text { range: } 0.8-4.2)\end{array}$ \\
\hline \multicolumn{4}{|l|}{$\mathrm{CH}$} \\
\hline At start of therapy & $\begin{array}{l}338.7 \pm 380.7 \text { (median: } \\
262.5, \text { range: } 38.0- \\
1890.0)\end{array}$ & Not available & \\
\hline At follow-up & $\begin{array}{l}1.9 \pm 1.6(\text { median: } 1.1 \\
\text { range: } 0.1-4.8)\end{array}$ & $\begin{array}{l}9.9 \pm 1.8 \text { (median: } 10.1 \text {, } \\
\text { range: } 5.2-13) \\
(3.5 \pm 0.8 \mathrm{pg} / \mathrm{mL} \text {, median: } \\
3.5 \text {, range: } 2.4-4.9)\end{array}$ & $\begin{array}{l}16.7 \pm 2.6 \text { (median: } 16.7, \\
\text { range: } 12.9-20.6) \\
(1.6 \pm 0.3 \mathrm{ng} / \mathrm{dL}, \text { median: } 1.6, \\
\text { range: } 0.8-2.4)\end{array}$ \\
\hline \multicolumn{4}{|l|}{ p-Value } \\
\hline For group comparison at follow-up & 0.49 & 0.25 & 0.17 \\
\hline
\end{tabular}



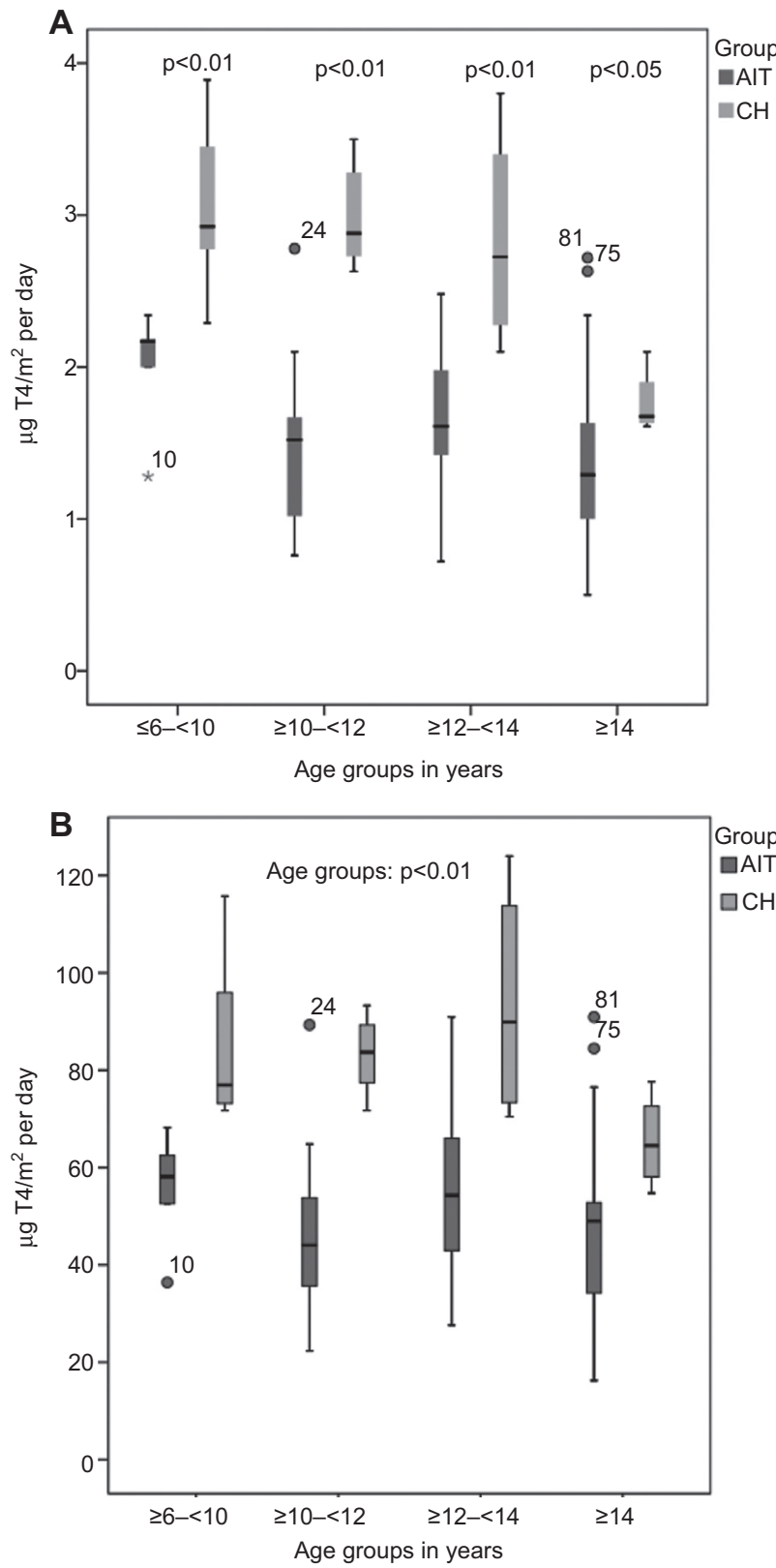

Figure 1 (A, B) Comparison of T4 dose in micrograms per kilogram per day ( $\mu \mathrm{g} / \mathrm{kg}$ day) and micrograms per square meter per day ( $\mu \mathrm{g} / \mathrm{m}^{2}$ per day) between groups divided by age. Boxplots show the median, minimum, maximum, 1st and 3rd quartile. Above the boxplots, the corresponding $\mathrm{p}$ value is indicated.

to $<12$ years, $3.0 \pm 0.3 \mu \mathrm{g}$ T4 $/ \mathrm{kg}$ per day; adolescents $>12$ to $<14$ years, $2.8 \pm 0.7 \mu \mathrm{g} \mathrm{T} 4 / \mathrm{kg}$ per day; and those aged $>14$ years, $1.8 \pm 0.2 \mu \mathrm{g} \mathrm{T} 4 / \mathrm{kg}$ per day.

The dose per body surface area is consistent with the dose per kilogram. The AIT subjects needed on average $50.2 \pm 17.2 \mu \mathrm{g} \mathrm{T} 4 / \mathrm{m}^{2}$ ( $\geq 6$ to $<10$ years: $55.6 \pm 12.1 \mu \mathrm{g} \mathrm{T} 4 / \mathrm{m}^{2}$; $\geq 10$ to $<12$ years, $55.2 \pm 15.3 \mu \mathrm{g} \mathrm{T} 4 / \mathrm{m}^{2}$; $\geq 12$ to $<14$ years: $46.3 \pm 16.7 \mu \mathrm{g} \mathrm{T} 4 / \mathrm{m}^{2}$; and $\geq 14$ years, $47.3 \pm 19.2 \mu \mathrm{g} \mathrm{T} 4 / \mathrm{m}^{2}$ ) for an optimal TSH, and the $\mathrm{CH}$ subjects required $82.5 \pm 16.8 \mu \mathrm{g} \mathrm{T} 4 / \mathrm{m}^{2}$ ( $\geq 6$ to $<10$ years: $93.5 \pm 24.9 \mu \mathrm{g} \mathrm{T} 4 / \mathrm{m}^{2}$; $\geq 10$ to $<12$ years, $85.0 \pm 15.9 \mu \mathrm{g} \mathrm{T} 4 / \mathrm{m}^{2} ; \geq 12$ to $<14$ years, $83.2 \pm 7.8 \mu \mathrm{g} \mathrm{T} 4 / \mathrm{m}^{2}$; $\geq 14$ years, $\left.65.4 \pm 9.7 \mu \mathrm{g} \mathrm{T} 4 / \mathrm{m}^{2}\right)(\mathrm{p}<0.01)$.

Focusing on the $\mathrm{CH}$ disease etiology, eight patients had an athyreosis (36.4\%), 12 had an ectopic thyroid gland (54.5\%) and two suffered from dyshormonogenesis $(9.1 \%)$. Patients with athyreosis required an average dose of $3.1 \pm 0.5 \mu \mathrm{g} \mathrm{T} 4 / \mathrm{kg}$ per day; patients with ectopia, $2.6 \pm 0.7 \mu \mathrm{g}$ T4/kg per day; and patients with dyshormonogenesis, $2.5 \pm 0.6 \mu \mathrm{g}$ T4/kg per day. Compared to each other, patients with athyreosis were given a significantly different dose $(p<0.01)$ than that given to patients with ectopia or dyshormonogenesis.

We also analyzed the different requirements for T4 by the disease severity (on the basis of the initial TSH). AIT patients who were mildly affected (with an initial TSH over the age-dependent cut-off value $>4.84 \mu \mathrm{IU} / \mathrm{mL}$ for 6-11-year-olds and $>4.30 \mu \mathrm{IU} / \mathrm{mL}$ for $11-20$-year-olds to $10 \mu \mathrm{IU} / \mathrm{mL}$ ) required a mean dose of $1.4 \pm 0.5 \mu \mathrm{g}$ T4 $/ \mathrm{kg}$ per day. Moderately affected children and adolescents with a TSH between 10 and $20 \mu \mathrm{IU} / \mathrm{mL}$ needed $1.7 \pm 0.4 \mu \mathrm{g}$ T4/ $\mathrm{kg}$ per day and severely affected patients with a TSH $>20$ $\mu \mathrm{IU} / \mathrm{mL}$ needed $1.8 \pm 0.5 \mu \mathrm{g} \mathrm{T} 4 / \mathrm{kg}$ per day.

Children and adolescents with $\mathrm{CH}$ were all severely affected with a TSH $>20 \mu \mathrm{IU} / \mathrm{mL}$ at birth. They required an average dose of $2.8 \pm 0.7 \mu \mathrm{g}$ T4/ $\mathrm{kg}$ per day. The T4 dosage between severely affected patients with AIT and CH differed significantly $(p<0.01)$.

\section{Discussion}

The novelty of this study is that, for the first time, the different dosage requirements of pediatric patients with autoimmune thyroiditis (AIT)-induced hypothyroidism and congenital hypothyroidism $(\mathrm{CH})$ were compared. The study is of special interest for all pediatricians due to the high prevalence of the disease. The direct comparison of patients with $\mathrm{CH}$ revealed a significantly lower dose necessary for the optimal treatment of patients with AIT than for patients with $\mathrm{CH}$.

The indication for treatment of AIT may be unclear in some cases; however, there is general agreement that patients with hypothyroidism should be treated with T4 and peripheral thyroid hormones should be adjusted in the upper half of normal range and TSH in the lower half of the normal range (15).

Our study focuses on a $\mathrm{T} 4$ dose recommendation per kilogram of body weight, which is more individual and 
practice related. Patients with $\mathrm{CH}$ were initially treated with a mean T4 dose of $13.0 \mu \mathrm{g}$ T4/kg per day shortly after birth, as recommended by several authors and societies (12-14). During the follow-up visit in adolescence, the $\mathrm{CH}$ patients received $2.8 \mu \mathrm{g}$ T4/kg per day. This also corresponds to the recommended dose of Taketomo et al. (12) and differed significantly from the dose $(1.5 \mu \mathrm{g} \mathrm{T} 4 / \mathrm{kg}$ per day) adequate for the AIT patients in our study. The dose by age also deviated significantly with $2.0 \mu \mathrm{g}$ T4/ $\mathrm{kg}$ per day ( $\geq 6$ to $<10$ years), $1.6 \mu \mathrm{g}$ T $/ \mathrm{kg}$ per day $(\geq 10$ to $<12$ years), $1.5 \mu \mathrm{g}$ T4/kg per day ( $\geq 12$ to $<14$ years) and $1.4 \mu \mathrm{g} T 4 / \mathrm{kg}$ per day ( $\geq 14$ years), respectively. In terms of dose per body surface, there was also a highly significant difference between the two groups. The AIT patients were optimally set up with $50 \mu \mathrm{g} \mathrm{T} 4 / \mathrm{m}^{2}$ per day, whereas the $\mathrm{CH}$ patients needed $83 \mu \mathrm{g} \mathrm{T} 4 / \mathrm{m}^{2}$ per day on average.

To date, there are two similar dose recommendations for therapy of AIT published in pediatric textbooks $(8,9)$. Unfortunately, neither gives a dose recommendation based on clinical studies and therefore they do not enlarge upon references, methods, inclusion criteria and TSH range. Latrofa and Pinchera (9) recommend $5 \mu \mathrm{g}$ T4/kg per day for 1-5-year-olds, $4 \mu \mathrm{g}$ T4/kg per day for 6-12-year-olds, $3 \mu \mathrm{g} \mathrm{T} / \mathrm{kg}$ per day for adolescents and $1.6 \mu \mathrm{g}$ T4/kg per day for young adults. In comparison, Brown (8) advises physicians to administer 4-6 $\mu \mathrm{g}$ T4/kg per day for 1-5-year-olds, 3-4 $\mu \mathrm{g}$ T4/kg per day for 6-10-year-olds and $2-3 \mu \mathrm{g}$ T4/kg per day for children 11 years and older. The calculated mean T4 dose requirements for AIT patients were significantly lower in our study.

Another argument in favor of this amount of T4 is the mean dose of $1.5 \mu \mathrm{g} / \mathrm{kg}$ per day, which was necessary to normalize the serum TSH concentrations of 114 children with a mean age of 11.8 years in a retrospective chart review by De Fries et al. (18).

Many authors advise treatment for juvenile AIT to follow the same guidelines for substitution of $\mathrm{CH}$, i.e., approximately $100 \mu \mathrm{g} \mathrm{T} 4 / \mathrm{m}^{2}$ per day $(13,14)$. This dosage is based mainly on two small studies from 1977. One study conducted by Abbassi and Aldige (19) focuses on the treatment of 15 hypothyroid children between 4 and 17 years. The authors identified a mean optimal dose of $3.5 \pm 0.3 \mu \mathrm{g} T 4 / \mathrm{kg}$ per day. The results of the other study by Rezvani and DiGeorge (20) for 11 hypothyroid children ages 1-14 are similar: $3.78 \pm 0.6 \mathrm{~T} 4 / \mathrm{kg}$ per day or $104.6 \pm 5.3$ $\mathrm{T} 4 / \mathrm{m}^{2}$ per day. However, our study with a higher patient number revealed that, in comparison to $\mathrm{CH}$ patients, a significantly lower dose of approximately $50 \mu \mathrm{g} \mathrm{T} 4 / \mathrm{m}^{2}$ per day $(\mathrm{p}<0.01)$ is needed to normalize the AIT patient's serum concentrations.

Likewise, a study conducted by Gordon and Gordon (21) in adult AIT patients supports administering T4 therapy depending on disease etiology. Results showed significantly different dosages for patients with atrophic thyroiditis, AIT, central hypothyroidism or status post thyroidectomy (21). This was also our finding. Patients with athyreosis required a significantly different average dose $(3.1 \pm 0.5 \mu \mathrm{g}$ T4/kg per day) than patients with ectopia ( $2.6 \pm 0.7 \mu \mathrm{g} \mathrm{T} 4 / \mathrm{kg}$ per day) or dyshormonogenesis $(2.5 \pm 0.6 \mu \mathrm{g} \mathrm{T} 4 / \mathrm{kg}$ per day) ( $<<0.01)$. In our study, the patient's dose also differed by disease severity. Severely affected children and adolescents with AIT and $\mathrm{CH}$ required a significantly different dosage $(\mathrm{p}<0.01)$.

Our T4 dosage recommendation for AIT patients is an average maintenance dose which should be individually adapted to the patients' current needs, since it is a known fact that the course of the disease varies in time (18, 22-24). Regular laboratory controls at least every 6 months and physical examinations are necessary for confirmation of therapy indication and dosage adaption.

In summary, patients with AIT-induced hypothyroidism need an average dose of $1.5 \mu \mathrm{g} / \mathrm{kg}$ per day ( $\geq 6$ to $<10$ years: $2.0 \mu \mathrm{g}$ T4/ kg per day; $\geq 10$ to $<12$ years: $1.6 \mu \mathrm{g}$ T4/kg per day; $\geq 12$ to $<14$ years: $1.5 \mu$ T $4 / \mathrm{kg}$ per day; $\geq 14$ years: $1.4 \mu \mathrm{g} \mathrm{T} 4 / \mathrm{kg}$ per day).

Physicians who prefer a maintenance dose per square meter should resort to $50 \mu \mathrm{g} \mathrm{T} 4 / \mathrm{m}^{2}$ as a guideline.

Received January 26, 2013; accepted May 14, 2013; previously published online June 8, 2013

\section{References}

1. Zois C, Stavrou I, Kalogera C, Svarna E, Dimoliatis I, et al. High prevalence of autoimmune thyroiditis in schoolchildren after elimination of iodine deficiency in northwestern Greece. Thyroid 2003;13:485-89.

2. Rallison ML, Dobyns BM, Meikle AW, Bishop M, Lyon JL, et al. Natural history of thyroid abnormalities: prevalence, incidence, and regression of thyroid diseases in adolescents and young adults. Am J Med Genet 1991;91:363-70.

3. Gaudino R, Garel C, Czernichow P, Léger J. Proportion of various types of thyroid disorders among newborns with congenital hypothyroidism and normally located gland: a regional cohort study. Clin Endocrinol (Oxf) 2005;62:444-8. 
4. Skordis N, Toumba M, Savva SC, Erakleous E, Topouzi M, et al. High prevalence of congenital hypothyroidism in the Greek Cypriot population: results of the neonatal screening program 1990-2000. J Pediatr Endocrinol Metab 2005;18:463-71.

5. Rivkees SA, Bode HH, Crawford JD. Long-term growth in juvenile acquired hypothyroidism: the failure to achieve normal adult stature. N Engl J Med 1988;318:599-602.

6. Rovet JF. Congenital hypothyroidism: long-term outcome. Thyroid 1999;9:741-8.

7. Arbeitsgemeinschaft Pädiatrische Endokrinologie (APE) als Sektion der Deutschen Gesellschaft für Kinderheilkunde und Jugendmedizin (DGKJ) sowie der Deutschen Gesellschaft für Endokrinologie (DGE) Sektion Pädiatrische Endokrinologie und Diabetologie (2012). Leitlinie Autoimmunthyreoiditis. Available at: http://www.awmf.org/leitlinien/detail/ll/ 027-040.html.

8. Brown RS. The thyroid. In: Brook C, Clayton P, Brown RS, editors. Brook's clinical pediatric endocrinology, 6th ed. New York: Wiley-Blackwell, 2009:250-81.

9. Latrofa F, Pinchera A. Autoimmune hypothyroidism. In: Weetman AP, editor. Autoimmune diseases in endocrinology, 12th ed. New Jersey: Humana Press, 2008:137-76.

10. Deutsche Gesellschaft für Endokrinologie, Deutsche Gesellschaft für Kinder- und Jugendmedizin e.V., Arbeitsgemeinschaft Pädiatrische Endokrinologie. Diagnostik, Therapie und Verlaufskontrolle der Primären angeborenen Hypothyreose. Available at: http://www.awmf.org/leitlinien/ detail/ll/027-017.html.

11. Rose SR, Brown RS, Foley T, Kaplowitz PB, Kaye Cl, et al. Update of newborn screening and therapy for congenital hypothyroidism. American Academy of Pediatrics and American Thyroid Association. Pediatrics 2006;117:2290-303.

12. Taketomo CK, Hodding JH, Kraus DM, editors. Lexi-Comp's pediatric dosage handbook with international trade names index: including neonatal dosing, drug administration, and extemporaneous preparations. American Pharmacist Association (APhA). Hudson, Ohio: Lexi-Comp, 2011.
13. Fisher DA, Grueters A. Thyroid disorders in childhood and adolescence. In: Sperling M, editor. Pediatric endocrinology, 3rd ed. Philadelphia: Saunders/Elsevier, 2008:227-53.

14. Van Vliet G. Hypothyroidism in infants, children and adolescents: Acquired hypothyroidism. In: Braverman LE, Utiger RD, editors. The thyroid: A fundamental and clinical text, 9th ed. Philadelphia: Lippincott Williams and Wilkins, 2005:1041-47.

15. Baloch Z, Carayon P, Conte-Devolx B, Demers LM, FeldtRasmussen $\mathrm{U}$, et al. Laboratory medicine practice guidelines. Laboratory support for the diagnosis and monitoring of thyroid disease. Thyroid 2003;13:3-126.

16. Roche Diagnostics $\mathrm{GmbH}$. Reference intervals for children and adults: Elecsys thyroid tests. Mannheim, Germany, 2009.

17. Mosteller RD. Simplified calculation of body surface area. N Engl J Med 1987;317:1098.

18. De Fries L, Bulvik S, Phillip M. Chronic autoimmune thyroiditis in children and adolescents: at presentation and during long-term follow-up. Am J Dis Child 2008;94:33-7.

19. Ábbassi V, Aldige C. Evaluation of sodium L-thyroxine (T4) requirement in replacement therapy of hypothyroidism. J Pediatr 1977;90:298.

20. Rezvani IR, DiGeorge AM. Reassessment of the daily dose of oral thyroxine for replacement therapy in hypothyroid children. J Pediatr 1977;90:291.

21. Gordon MB, Gordon MS. Variations in adequate levothyroxine replacement therapy in patients with different causes of. hypothyroidism. Endocr Pract 1999;5:233-8.

22. Radetti G, Gottardi E, Bona G, Corrias A, Salardi S, et al. The natural history of euthyroid Hashimoto's thyroiditis in children. J Pediatr 2006;149:827-32.

23. Fava A, Oliverio R, Giuliano S, Parlato G, Michniewicz A, et al. Clinical evolution of autoimmune thyroiditis in children and adolescents. Thyroid 2009;19:361-7.

24. Özen S, Berk Ö, Simsek DG, Darcan S. Clinical course of Hashimoto's thyroiditis and effects of levothyroxine therapy on the clinical course of the disease in children and adolescents. J Clin Res Pediatr Endocrinol 2011;3:192-7. 